\title{
Ideologi dan Gerakan Sosial Islam Syiah (Kajian Sosiologi Profetik) di Kota Makassar
}

\author{
Syahban Nur ${ }^{1}$ Irmawati $^{2}$ \\ ${ }^{1}$ Pendidikan Sosiologi, Universitas Muhammadiyah Makassar \\ Email: syahban@unismuh.ac.id \\ ${ }^{2}$ Pendidikan Sosiologi, Universitas Muhammadiyah Makassar \\ Email: irmawati@gmail.com
}

\begin{abstract}
Abstrack. This research is qualitative research through a phenomenological approach which aims to (i) to find out the existence of Shi'ite Islam in Makassar City (ii) to find out the ideological forms and social movements of Shi'ite Islam in Makassar City. The study population is a member of the Syi'ah group and sampling uses the technique of determining linear snowball sampling, data collection methods are observation, interviews, and documentation. The results showed that (i) the level of existence of Syi'ah in Makassar was very minimal because the community was very opposed to the existence of Syi'ah itself. Even they were silent hearing Syiah's words. Because the existence of Syi'ah will have a bad influence on society. (ii) Social movements carried out by the IJABI community in Makassar City such as carrying out prayers and carrying out various preaching activities. One of the preaching activities carried out was the Haul Syahadah Imam Husain Cucunda Rasulullah (ASYURA) in 2017. This activity has been going on for a long time because there was no positive response from the government regarding the activity. The Syi'ah community easily influenced students in the city of Makassar through the teachings of nikah mut'ah.
\end{abstract}

Keywords: Ideology, Social, Movement.

Abstrak. Penelitian ini adalah penelitian kualitatif melalui pendekatan fenomologi yang bertujuan adalah (i) untuk mengetahui eksistensi Islam Syiah di Kota Makassar (ii) untuk mengetahui bentuk ideologi dan gerakan sosial Islam Syi'ah di Kota Makassar. Adapun populasi penelitian adalah anggota kelompok Syiah dan pengambilan sampel mengunakan teknik penentuan informan linear snowball sampling Metode pengumpulan data adalah observasi, wawancara, dan dokumentasi. Hasil penelitian menunjukan bahawa (i) Tingkat keeksistensian syiah di Kota Makassar itu sangat minim dikarenakan masyarakat sangat menentang dengan keberadaan syiah itu sendiri. Bahkan mereka bungkam mendengar kata Syi'ah. Karena dengan adanya Syi'ah akan membawa pengaruh buruk bagi masyarakat. (ii) Gerakan sosial yang dilakukan oleh komunitas IJABI di Kota Makassar seperti melaksanakan doa-doa dan melakukan berbagai kegiatan dakwah. Salah satu kegiatan dakwah yang dilaksanakan yaitu Haul Syahadah Imam Husain Cucunda Rasulullah (ASYURA) pada tahun 2017 silam. Kegiatan ini sudah berlangsung lama dikarenakan tidak adanya respon positif dari pihak pemerintah tentang kegiatan tersebut. Komunitas Syi'ah dengan mudahnya mempengaruhi mahasiswa-mahasiswa di kota Makassar melalui ajaran nikah mut’ah.

Kata Kunci: Ideologi, Gerakan, Sosial.

\section{PENDAHULUAN}

Indonesia merupakan salah satu pemeluk agama islam terbesar, jumlah penduduk islam juga bertambah seiring dengan perkembangan zaman. Bermula dari kawasan Saudi Arabia, yaitu pada dua kota utama yaitu Kota Mekah tempat Rasul Muhammad dilahirkan dan Madinah sebagai pusat perkembangan awal Islam. Di kota Madinah inilah terjalinnya integrasi sosioreligius antara kaum 
muhajirin (pendatang) dan anshor (penduduk Madinah). Mereka dipersatukan Rasul Muhammad berdasarkan konsep persaudaraan. Proses migrasi Nabi Muhammad dan para pengikutnya dari Mekah ke Madinah ini menjadi dasar dari sistem kalender Hijriah Islam. Akhirnya Islam berkembang ke seluruh Jazirah Arab, Persia, Asia Selatan, China, Eropa Barat dan Timur, Nusantara (Asia Tenggara), dan kini ke seluruh penjuru dunia. Islam adalah agama yang paling pesat perkembangan jumlah pengikutnya dalam beberapa abad terakhir ini.

Kebesaran Islam bukan hanya terlihat dari jumlah pengikutnya namun Islam juga memiliki banyak aliran yang berbeda dalam menafsirkan dan mengamalkan perintah dalam Al-Qur'an dan Hadits. Yang paling jelas ada dua aliran dalam Islam yaitu Ahlusunna wal Jama'ah atau lazim disebut kelompok Suni dan Syi'ah atau Syi'i. Di dalam masyarakat muslimSunni sendiri terdapat empat mazhab besar berdasarkan imam yang mereka ikuti, yaitu: Maliki, Hanafi, Hanbali, dan Syafi'i. Demikian pula di dalam masyarakat muslim Syi'ah terdapat berbagai aliran lagi. Islam adalah agama samawiyah yang dibawa oleh Nabi Muhammad.SAW. Inti ajaranya adalah percaya kepada Allah Yang Ahad, yang diucapkan dan dibenarkan dalam hati yaitu Tiada Tuhan selain Allah dan Muhammad itu adalah utusan (Rasul) Allah. Di dalam Islam juga dikenali dua rukun utama agama ini, yaitu rukun Islam dan rukun Iman. Rukun Islam adalah syariat dalam bentuk lima aktivitas dan rukun Iman yang terdiri dari enam aktivitas. Di lain sisi rukun iman berikut ini adalah menurut aliran Islam Syi'ah (dikenal sebagai ushulluddin yaitu prinsip-prinsip keimanan) terdiri dari: (1) At-tauhid yaitu keesaan Allah, (2) Al-adhalah yaitu kejadian Allah, (3) An-nubuwah yaitu kenabian, (4) Al-imamah yaitu kepemimpinan pasca Nabi Muhammad SAW., dan (5) Al-ma'ad.

Aktivitas Islam secara umum dapat terlihat dari pengamalan lima rukun islam yang wajib dilaksanakan sebagai bentuk rasa patuh kepada Allah dengan mencontoh segala amal perbuatan yang dilakukan oleh Rasulullah Muhammad SAW. Dalam mencontoh segala amalan yang dilakukan oleh Rasul tidak hanya terbatas oleh bentuk pelaksanaannya secara lahiriah saja namun bentuk amalan itu juga harus disertai dengan mencontoh rasa batiniah Rasul. Hal inilah yang banyak menjadi perbincangan diberbagai aliran di dalam Islam tentang bagaimana melakukan pendekatan tentang maksud dari tiap-tiap ayat yang terkandung dalam Al-Qur'an dan Hadits, karena Al-Qur'an tidak hanya dapat dimaknai dengan arti tersirat yang lebih mendalam.

Islam itu mengajarkan pemeluknya melaksanakan ibadah secara rutin, ibadah yang dilakukan terasa lebih baik jika dilakukan dengan ikhlas sesuai dengan tuntutan yang diajarkan oleh Rasulullah SAW. Islam sering disalahpahami, khususnya dengan diidentikkan dengan muslim. Islam dan muslim adalah dua istilah yang berbeda. Islam adalah agama sedangkan, muslim adalah pemeluknya. Islam sering diidentikkan dengan perilaku kaum muslim atau umat islam. Padahal, sebagai perilaku penganut agama lainnya, perilaku seorang muslim belum tentu mencerminkan ajaran atau syariat islam.

Berbeda lagi dengan Syi'ah. Syi'ah dalam bahasa Arab ialah salah satu aliran atau mazhab dalam islam. Syi'ah menolak kepemimpinan dari tiga khalifah sunni pertama seperti juga sunni menolak imam dari imam Syi'ah. Syi'ah menurut etimologi bahasa Arab bermakna pembela dan pengikut seseorang. Selain itu juga bermakna setiap kaum yang berkumpul di atas suatu perkara. Mengenai kemunculan Syi'ah dalam sejarah terdapat dikalangan ahli. Menurut Abu Zahrah, Syi'ah muncul pada masa akhir pemerintahan Usman bin Affan kemudian tumbuh dan berkembang pada masa pemerintahan Ali bin Abi Thalib. Kalangan Syi'ah sendiri berpendapat bahwa kemunculan Syi'ah berkaitan dengan masalah pengganti Nabi Muhammad Saw. Mereka menolak kekhalifahan Abu Bakar, Umar bin Khathtab dan Usman bin Affan karena dalam pandangan mereka hanya Ali bin Abi Thalib yang berhak menggantikan Nabi Muhammad Saw. Kepemimpinan ali dalam pandangan Syi'ah tersebut berjalan dengan isyarat yang diberikan Nabi Muhammad Saw, pada masa hidupnya. Bukti sahnya Ali sebagai penerus Nabi Muhammad adalah peristiwa Ghadir Khumm. Diceritakan bahwa kembali dari haji terakhir, dalam perjalanan dari Mekkah ke Madinah disuatu padang pasir yang bernama Ghadir Khumm. Berlawanan dengan harapan mereka, ketika Nabi Muhammad wafat dan jasadnya belum dikuburkan, ada kelompok lain yang pergi ke mesjid untuk menentukan pemimpin yang kalangan kaum muslimin yang menentang kekahalifahan dan kaum baru karena hilangnya 
pemimpin secara tiba-tiba. Karena kenyataan itulah muncul suatu sikap dari mayoritas dalam masalah-masalah kepercayaan tertentu. Mereka tetap berpendapat bahwa semua masalah kerohanian dan agama harus merujuk kepadanya dan mengajak masyarakat mengikutinya. Kaum inilah yang disebut dengan kaum Syi'ah. Namun lebih dari pada itu, munculnya Syi'ah terletak pada kenyataan bahwa kemungkinan ini ada dalam wahyu islam sendiri, sehingga mesti diwujudkan.

Syi'ah mendapatkan pengikut yang besar terutama pada masa dinasti Amawiyah karena mendapatkan perlakuan kasar. Diantara bentuk kekerasan itu adalah dipintahnya pasukan yang dipimpin oleh Ibnu Ziyad untuk memenggal kepala Husein bin Ali. Meskipun mempunyai landasan keimanan yang sama, Syiah tidak dapat mempertahankan kesatuannya. Dalam perjalan sejarah, kelompok ini akhirnya terpecah.

Sedangkan, Ideologi adalah sebuah istilah yang lahir pada abad ke-18 atau tahun 1766 yang dikemukakan oleh filsuf Perancis bernama Destutt de Tracy dan kemudian dipakai oleh Napoleon. Istilah itu berasal dari dua kata ideos yang berarti gagasan, dan logos yang berarti ilmu. Dengan demikian, ideologi adalah sebuah ilmu tentang gagasan. Ideologi yang benar adalah ideologi yang muncul di dalam pemikiran manusia melalui wahyu Allah, karena ideologi ini bersumber dari pencipta alam semesta, manusia dan kehidupan, yang maha mengetahui segala sesuatu, sehingga pemecahan atas permasalahan pokok kehidupan dan berbagai permasalahan kehidupan lainnya kebenarannya pasti. Sedangkan ideologi yang muncul di dalam pemikiran manusia karena kejeniusannya adalah ideologi yang salah, karena manusia hanyalah makhluk Allah sehingga memiliki kelemahan termasuk ketidakmampuan akalnya dalam menangkap seluruh realitas yang ada di dunia ini. Manusia juga selalu memiliki pandangan yang berbeda terhadap suatu masalah seperti masalah hukum dan kebijakan publik sehingga muncul pertentangan dan perselisihan yang menyebabkan pandangan mayoritas atau mungkin hanya pandangan-pandangan orang yang memiliki kekuatan di atas orang lainnya yang akan diterapkan atau dipaksakan.

Adapun beberapa penelitian yang terdahulu yang berhubungan dengan penelitian ini yaitu penelitian yang dilakukan oleh Haryanto, Siti Mauliana Hairini dan Abu bakar dalam Jurnal IImu Sosial dan IImu Politik Fakultas IImu Sosial dan Politik Universitas Gadjah Mada pada tahun 2013. Penelitian tersebut berjudul PKBI: Aktor Intermediary dan Gerakan Sosial Baru. Dalam penelitian tersebut meneliti bagaimana PKBI (Perkumpulan Keluarga Berencana Indonesia) mampu menjadi sosok Intermediary yang memperjuangkan hak-hak menggunakan pendekatan Gerakan Sosial Baru. Hasil penelitiannya adalah bahwa Gerakan Sosial Baru dalam konteks politik tidak hanya terjadi d Eropa atau Amerika tetapi terjadi juga dilndonesia disebabkan karena pengaruh globalisasi banyak mengubah mainstream pada agensi sosial.

Dan Penelitian yang dilakukan oleh Pidada, 2013 dalam tesisnya yang berjudul Gerakan Sosial Menuju Masyarakat Sipil. Pendekatan yang digunakan dalam penelitiannya itu adalah cultural studies dan fakta-fakta yang digunakan untuk menjawab masalah penelitiannya dibedah berdasarkan Teori Kritis, Teori Konflik dan Teori Hegemoni.

Isu yang awalnya berasal dari persoalan politik ini pun berkembang bahkan memunculkan perbedaan dalam memahami Islam. Bagi orang-orang yang tergolong dalam kelompok Syi'ah yang ada di Kota Makassar, Al-Qur'an yang dipakai oleh umat Islam sekarang ini sudah dipalsukan oleh Utsman bin Affan karena mereka menggunakan mushaf Utsmani. Menurut mereka, Al-Qur'an yang asli dibawa oleh Imam ke dua belas yang akan menjelma menjadi imam Mahdi. Demikian juga, dalam permasalahan syariat, Syi'ah memandang bahwa sholat lebih utama jika menghadap batu atau tanah karbala yang merupakan perlambang dari terbunuhnya Hussein bin Ali pada tahun $680 \mathrm{M}$ di Karbala (Kelidar, 1983). Selain itu, ada banyak perbedaan syariat lainnya termasuk masalah nikah mut'ah. Namun demikian, dalam konteks politik sebagai kelompok yang merasa selama ini di diskriminasi dan tertekan, Syi'ah punya misi besar untuk menSyi'ahkan dunia Islam. Mereka dengan Bahasa sederhana mendukung semangat terbentuknya khalifah Syi'ah. Tentu saja untuk upaya ini mereka perlu melakukan berbagai strategi untuk menarik simpati dunia Islam, termasuk upaya menguasai berbagai daerah yang ada di sekitar kota Makassar. 
Kota Makassar salah satunya merupakan kota dimana golongan Syi'ah berada, khususnya di daerah Perintis Kemerdekaan VI. Oleh karena itu, peneliti mengangkat judul "Ideologi dan Gerakan Sosial Islam Syi'ah (Kajian Sosiologi Profetik) di Kota Makassar.

\section{METODE PENELITIAN}

Jenis penelitian ini adalah kualitatif melalui pendekatan fenemologi di jalan Perintis Kemerdekaan VI Kota Makassar. Instrument penelitian ini adalah peneliti sendiri (human instrument) dengan menggunakan alat bantu berupa pedoman wawancara, instrument dokumentasi dan catatan observasi, alat perekam dan kamera. Pemilihan informan dilakukan secara linear snowball sampling sehingga subyek penelitian terdapat 3 orang yang terglong dalam Syi'ah. Focus Eksistensi islam Syi'ah serta bentuk Ideologi dan gerakan sosial Islam Syi'ah. Jenis data terdiri dari data primer dan sekunder. Teknik pengumpulan data menggunakan metode observasi, wawancara mendalam, dokumentasi. Analisis data dilakukan melalui tahapan reduksi data (data reduction), penyajian data (display data) verivication dan penarikan kesimpulan. Sedangkan teknik keabsahan data meliputi uji credibility (validitas internal), transferability (validitas eksternal), dependability (reliabilitas) dan confirmability (objektivitas).

\section{HASIL DAN PEMBAHASAN}

\section{a. Bentuk ideologi Syi'ah di Kota Makassar}

Ideologi syiah selalu dinisbahkan ke madzhab ja'fari, meskipun tidak ada hubungan sama sekali antara madzhab ja'fari dengan madzhab syiah, karena sebagian besar karya fiqih syiah imamiyah ditulis setelah lebih dari dua ratus tahun kematian ja'far shodiq. Atau bisa dikatakan sanadnya tidak terhubung/terputus.

Ada beberapa konsep dasar pemikiran Syi'ah. Hal itu disampaikan oleh bapak Yudi selaku pengurus di komunitas IJABI di Kota Makassar yang menyatakan bahwa :

"Konsep dasar pemikiran Syi'ah itu banyak, tetapi yang paling umum dikenal yaitu ada aqidah, syari'at dan muamalah" (wawancara 13 Juli 2018)

Berikut penjelasan mengenai konsep dasar pemikiran Syi'ah :

1. Aqidah

Doktrin aqidah kaum Syi'ah secara umum merupakan pengejawantahan dari keesaan ilahi dan kemah berkehendak-Nya. Adapun beberapa penjabaran doktrin utama kaum Syi'ah yaitu :

a. Allah Swt. adalah Zat Tunggal dan Maha Esa serta memiliki kekuasaan serta maha adil yang keadilan_Nya meliputi semua ciptaannya.

b. Allah Swt., menurunkan Nabinya untuk menjadi pembimbing umat yang ada dimuka bumi serta menjadi rahmat bagi seluruh alam semesta, rasulullah tidak begitu saja pergi meninggalkan umatnya setelah disempurnakan oleh Allah Swt. agama yang telah dibawanya melainkan telah menunjuk seseorang dari kalangan yang dipercayainya untuk melakukan pembimbingan terhadap umat yang ditinggalkan oleh Rasulullah, dan orang yang diberikan amanah untuk memimpin pasca kenabian adalah Imam Ali as. Selanjutnya diserahkan kepada Hasan, Husein, Ali Zainal Abidin.

c. Prinsip-prinsip eskatologis

Pada dasarnya prinsip ini adalah sebuah argumentasi tentang pembuktian akan adanya hari kiamat dan hari kebangkitan setelahnya. Doktrin ini sangatlah mempengaruhi perbedaan cara pandang mazhab syi'ah dengan mazhab yang lain dalam menjelaskan haqiqat kehidupan yang dijalani oleh umat manusia beserta beberapa konsekuensi hidupnya.

2. Syari'at

Dalam wilayah syari'at sebenarnya kaum Syi'ah memiliki doktrin yang tidak berbeda jauh dengan yang lain, dikarenakan beberapa perbedaan syari'at yang sering dinitsbahkan kepada kaum syi'ah diantaranya shalat dengan lurus tangan, menyatukan waktu-waktu shalat tanpa ada halangan, 
nikah mut'ah, memiliki beberapa persamaan dengan kalangan mazhab yang lain dari kalangan sunni. Mazhab maliki membolehkan shalat dengan lurus tangan, mazhab hanafi membolehkan menjamak shalat tanpa halangan, kecuali nikah mut'ah yang bagi kalangan sunni dalil-dalil yang merujuknya telah dinasakh oleh adanya ayat-ayat yang lain. Hal ini menjelaskan bahwa resistensi perbedaan mazhab syi'ah dalam persoalan syari'at tidak pentng untuk dipertajam. Perbedaan pendapat seputar syari'at antara mazhab syi'ah tidak jauh berbeda dengan mazhab sunni. Perbedaan mencolok antara penganut mazhab syi'ah dan sunni hanyalah pada persoalan pentingnya posisi kepemimpinan dipegang oleh orang memiliki sandaran dalil yang sah.

3. Muamalah

Produk pemikiran syi'ah dalam bidang muamalah yang berbeda dengan kaum sunni adalah aturan tentang khumus. Khumus adalah pembebanan zakat kepada orang yang memiliki harta yang tidak bergerak selama setahun seperlima. Kewajiban ini memungkinkan pengelolaan ketatanegaraan di bidang ekonomi yang baik sebab apabila terdapat harta yang tidak bergerak selama setahun, maka akan menyebabkan pengumpulan modal di tangan seseorang dan berpotensi menyebabkan krisis ekonomi. Analisis lainnya adalah dengan dikeluarkannya khumus akan menyebabkan pengelolaan sektor lain yang lebih baik.

Adapun dasar dalam pemikiran Syi'ah diantaranya yaitu tidak mungkin Allah Swt. dilihat dari aspek keadilan dan kemaha pengasih-Nya tidak mementingkan persoalan kepemimpinan dan orang yang memiliki pengetahuan rendah tidak layak untuk melahirkan produk hukum menjadi sandaran umat Islam dalam menjalankan kehidupannya.

Pendapat serupa juga diungkapkan oleh ustadz H. Muh. Said Abdul Shamad, Lc yang pernah melakukan penelitian di Iran, yaitu:

"Ideologi-ideologi Syi'ah banyak yang menyelisihi pemahaman ahlus sunnah wal jamaah dalam memahami ajaran Islam. (wawancara 10 Juli 2018)

Berdasarkan penjelasan dari ustadz Said, berikut beberapa penjelasan mengenai pemikiran Syi'ah yang menyelisih pemahaman dalam memahami ajaran Islam, yaitu :

1. Dalam bidang aqidah

Syi'ah menganggap bahwa ilmu tauhid adalah ilmu yang paling sesat bertolak belakang dengan pandangan ahlu sunnah wal jamaah yang meyakini bahwa ilmu tauhid adalah ilmu yang utama. Diantara kesesatan Syi'ah dalam bidang akidah adalah :

a. Keyakinan dalam menyertakan ali bin abi thalib dalm persaksian yang diberikan kepada Rasulullah Saw. Hal itu karena mereka menakwilkan ayat Allah (Al-A'raf: 172) dan mengatakan Muhammad adalah Rasulullah sedang Ali adalah amirul mukminim.

1. Keyakinan bahwa asma allah adalah hadis dan keyakinan bahwa yang dimaksud asmaullah adalah para aimmah Syi'ah.

2. Pengingkaran mereka bahwa orang mukmin dapat melihat Allah pada hari kiamat.

2. Dalam masalah nubuwah (kenabian)

Diantara kekeliruan Syi'ah dalam bidang nubuwah, yaitu :

a. Ishmah, mereka meyakini bahwa para pemimpin mereka maksum seperti Rasulullah Saw.

b. Pemimpin Syi'ah lebih utama daripada para Nabi dan Malaikat.

3. Dalam masalah imamah

a. Imamah sesuai keyakinan mereka harus dengan tekstual. Imam terdahulu harus menentukan imam penggantinya secara tekstual dan langsung ditunjuk orangnya, bukan dengan bahasa isyarat. Imamah sesuatu yang sangat penting yang tidak boleh terpisahkan antara Rasulullah Saw dengan umat dan tidak boleh dibiarkan masing-masing orang menyampaikan pendapatnya tentang imamah sendiri. 
b. Bada' yaitu faham yang meyakini bahwa Allah bisa salah dalam menetapkan sesuatu.

c. Taqiyah, dianggap sebagai salah satu pokok ajaran agama. Barangsiapa yang meninggalkan taqiyah sama hukumnya meninggalkan sholat. Barangsiapa yang meninggalkannya sebelum ia tampil maka ia telah keluar dari agama Allah dan agama imamiyah.

Raj'ah, orang yang pertama berpendapat raj'ah dalam Syi'ah adalah abdullah ibn sab'ah yahudi, dengan berkata "saya kagum pada orang yang berkata isa akan kembali tetapi tidak berkata Muhammad akan kembali. Maka ketika ali terbunuh, ia mulai menyebarkan isu bahwa Ali belum terbunuh,tetapi diangkat ke langit dan akan kembali ke dunia.

4. Dalam bidang fikih

a. Nikah Mut'ah (kawin kontrak)

Syi'ah imamiyah menghalalkan nikah mut'ah dan allah memberi pahala banyak bagi yang melakukannya, sesuai dalilnya dalam surat an-nisa ayat 24 .

b. Madzhab Syi'ah selalu dinisbahkan ke madzhab ja'fari, meskipun tidak ada hubungan sama sekali antara madzhab ja'fari dengan madzhab syi'ah, karena sebagian besar karya fiqih Syi'ah imamiyah ditulis setelah lebih dari dua ratus tahun kematian ja'far shodiq.

\section{a. Gerakan Sosial Islam Syi'ah di Kota Makassar}

Gerakan Syi'ah di Indonesia saat ini diorganisir oleh Islamic Cultural Center (ICC), dipimpin oleh Syaikh Mohsen Hakimollah, yang datang langsung dari Iran. Secara formal organisasi ini bergerak dalam bidang pendidikan dan dakwah. Dalam bidang dakwah, ICC bergerak di dua sektor, yaitu sektor pertama gerakan kemasyarakatan yang dijalankan oleh Ikatan jamaah Ahlulbait (IJABI), ke dua, gerakan politik yang dijalankan oleh yayasan OASE.

Di Kota Makassar, gerakan sosial Syi'ah itu sendiri ditandai dengan adanya komunitas IJABI. Hal tersebut diungkapkan oleh bapak Yudi sebagai pengikut Syi'ah di Kota Makassar bahwa :

"Komunitas IJABI sebagai motor gerakan kemasyarakatan, hingga sekarang strukturnya telah meluas secara nasional hingga di Daerah Tingkat II." (wawancara 13 Juli 2017)

Kader-kader IJABI selain telah banyak yang aktif di dunia kampus, kelompok-kelompok pengajian, lembaga-lembaga sosial dan media, di daerah-daerah juga telah banyak yang yang menjadi anggota parlemen. Di level inilah IJABI memiliki peranan penting sebagai simpul gerakan dakwah dan politik di masing-masing daerah.

Gerakan sosial yang dilakukan oleh komunitas IJABI di Kota Makassar seperti melaksanakan doa-doa dan melakukan berbagai kegiatan dakwah. Salah satu kegiatan dakwah yang dilaksanakan yaitu Haul Syahadah Imam Husain Cucunda Rasulullah (ASYURA) pada tahun 2017 silam. Kegiatan ini sudah berlangsung lama dikarenakan tidak adanya respon positif dari pihak pemerintah tentang kegiatan tersebut.

Saat ini para pengikut IJABI yang memiliki titik kumpul di daerah Perintis Kemerdekaan VI sudah tidak lagi melaksanakan berbagai kegiatan dikarenakan para pengikut IJABI ini sudah memiliki kesibukan dan berbagai kegiatan masing-masing. Bahkan untuk berkomunikasi saat ini mereka hanya memanfaatkan social media yang ada untuk tetap menjalin silaturrahmi satu sama lain.

Dalam memberikan pengajaran, mereka menggunakan ayat-ayat al-qur'an, tafsir-tafsir al-qur'an tidak melalui hadits atau sunnah. Karena mereka jauh sekali dari sunnah nabi SAW bahkan mereka menolak hadits. Mereka juga memvonis kufur kepada ahlus sunnah termasuk Bukhari, Muslim dan Ulama ahli hadits lainnya. Oleh karena itu, mereka selalu memulainya dengan tafsir yang meruju' ke kitab-kitab tafsir syi'ah. Melalui kajian tafsir-tafsir al-qur'an yang awalnya biasa tapi lama kelamaan menjadi aneh, karena seluruh ayat al-qur'an mereka tafsirkan dengan penafsiran mereka. Mereka selalu membuka kajian tafsir al-qur'an, tidak ada yang membuka kajian shahih bukhari kecuali untuk di hina, dikritik dan selanjutnya di tolak. Mereka mulai mentafsirkan ini untul Ali Radhiyallahu 'anhu dan siksaan ini untuk Abu Bakar Radhiyallahu 'anhu dan sebagainya. Syi'ah menempuh cara-cara 
kaum zindiq yaitu meninggikan sebagian dan merendahkan sebagian dalam waktu yang bersamaanagar mereka dapat menghancurkan secara keseluruhan.

Selain itu, mereka juga mengkritik hadits dalam shahih bukhari yang dinyatakan tidak sah, mustahil atau dusta. Semua justifikasi ini berdasarkan akal dan rayu mereka yang jahil dan itulah salah satu sifat mereka, mengkritik, membantah, dan menolak tanpa hujjah. Oleh karena itu ahlus sunnah menyatakan bahwa bantahan dan penolakan semata bukanlah ilmu. IImu adalah memberikan jawaban ilmiyah, membantah ilmiyah dengan menegakkan hujjah yang selanjutnya menyelesaikan permasalahan. Bahkan mereka memberikan kesan kepada masyarakat bahwa Syi'ah merupakan madzhab yang kelima dalam Islam dan perbedaan mereka adalah perbedaan furu'iyah, ijtihadiyah, ilmiyah secara global tanpa ta'shil dan tafshil sehingga ini juga mempengaruhi kaum muslimin.

Syi'ah juga mendakwahkan ajaran yang sangat menarik bagi orang-orang yang memiliki penyakit hati yaitu nikah mut'ah. Nikah mut'ah (nikah kontrak) tanpa wali tanpa saksi kecuali dengan mahar pemberian dan ada ikatan perjanjian antara kedua pihak laki dan wanita. Biasanya dilakukan selepas majlis mereka, mereka mengikat perjanjian kontrak satu hari, dua hari dan seterusnya dan boleh untuk satu kali berhubungan saja. Mereka berusaha menjauhkan kaum muslimin dan memberikan kesan buruk terhadap sebuah ajaran yang mereka benci yaitu wahabi. Kalimat ini sering diulang-ulang, tanpa ada penjelasan terperinci, siapa dan apa ajaran wahabi itu. Sehingga setiap ajaran dakwah atau yang berlawanan dengan Syi'ah dijauhi oleh kaum muslimin.

Syi'ah memasuki semua lapisan masyarakat dengan cara-cara yang berbeda, berikut penjelasannya yaitu :

1. Mereka mempengaruhi masyarakat awam dengan cara-cara yang dapat diterima oleh orangorang awam. Dikalangan orang-orang awam ini, mereka tidak akan mampu mengkafirkan seluruh para sahabat karena orang-orang awam walaupun mereka beragama dengan cara taqlid buta, mereka sangat mencintai para sahabat. Untuk mendekati masyarakat awam dengan kultus terhadap manusia atas nama ahlul bait. Bahkan mereka membuat berbagai bait-bait syair yang mengantarkan kepada pengkultusan terhadap Nabi. Dimulai dengan mengatasnamakan ahlul bait kemudian pemujaan terhadap manusia dengan membangun kubur-kubur serta meminta kepada penghuni kubur serta penyebaran berbagai macam bid'ah lainnya yang berasal dari Syi'ah.

2. Mendakwahi para pelajar khususnya mahasiswa. Mereka masuk lewat penyebaran nikah mut'ah karena para pemuda ini memang sangat aktifmencari hal-hal baru untuk kemudian dicoba. Setelah memberikan kenikmatan syaithanyah, mereka mulai mendekati para pemuda ini dengan memberikan gambaran bahwa ajaran Syi'ah itu benar. Oleh karena itu tokoh-tokoh mereka mengajar diberbagai perguruan tinggi untuk menjerat para mahasiswa yang mayoritasnya kosong dari ajaran islam, aqidah shahihah serta tidak gemar duduk di majlis-majlis ahli ilmu. Para mahasiswa ini terus didekati sampai akhirnya menjadi Rafidhah tulen dan diharapkan menjadi kaum intelektual yang memegang pemerintahan di negeri ini.

3. Memasuki media massa, yang cetak maupun elektronik. Melalui media-media ini, mereka menampilkan Rafidhah sedikit demi sedikit, dengan dalih sebagai khazanah islamiyah. Namun tentunya mereka tidak terang-terangan membawakan ajaran mereka.

4. Mereka memberikan pengajaran kepada kaum intelektual khususnya kepada pendukung mereka. Mereka mendapat dukungan kuat sehingga paling tidak kaum intelektual ini bersikap netral atau toleran tidak mempermasalahkan anatara Sunni dengan Syi'ah.

5. Mendekati para pejabat negeri yang memegang tampuk pemerintahan untuk diberikan pelajaran tentang Syi'ah.

6. Masuk ke partai politik dengan menjadi tim-tim sukses partai politik.

7. Membuat pengajian untuk ibu-ibu karena peran wanita sangat penting sekali dan sangat besar sekali. Oleh karena itu mereka membutuhkan ibu-ibu untuk mendukung ajaran mereka. 


\section{Sekte-sekte dalam aliran Syi'ah}

Dalam perkembangannya Syi'ah terpecah menjadi 22 aliran. Diantaranya yaitu :

1. Syi'ah Al-Kaisaniyah

Syi'ah Al-Kaisaniyah tidak mempercayai keberadaan ruh dalam tubuh Ali tetapi mereka yakin bahwa para imam orang Syi'ah adalah ma'shum. Selain itu mereka beranggapan bahwa Allah Swt. Itu mengubah kehendak-Nya menurut perubahan ilmu-Nya. Allah Swt. Memerintahkan sesuatu, kemudian memerintah pula kebalikannya dan mereka mempercayai roh.

2. Syi'ah Zaidiyah

Syi'ah Zaidiyah ber'itiqad bahwa orang muslim yang melakukan dosa besar, kalau mati sebelum bertobat ia kafir dan kekal di dalam neraka. Syi'ah zaidiyah juga berpendapat bahwa bolehnya membaiat dua orang imam pada satu daerah, yang mana masing-masing imam itu menjadi imam yang dia keluar padanya.

3. Syi'ah sabaiyah

Syi'ah sabaiyah adalah syi'ah pengikut abdullah bin saba, golongan syi'ah ini termasuk golongan yang gullat artinya syi'ah yang berlebihan karena mempercayai bahwa Nabi Muhammad akan kembali ke dunia seperti Nabi Isa. Mereka meyakini bahwa Ali belum mati tetapi bersembunyi dan akan lahir ke dunia kembali.

\section{KESIMPULAN}

Berdasarkan hasil penelitian dan pembahasan maka kesimpulan dalam penelitian adalah (i) Tingkat ke-eksistensian Syi'ah di Kota Makassar itu sangat minim dikarenakan masyarakat sangat menentang dengan keberadaan Syi'ah itu sendiri. Bahkan mereka bungkam mendengar kata Syi'ah. Karena dengan adanya Syi'ah akan membawa pengaruh buruk bagi masyarakat. (ii) Gerakan sosial yang dilakukan oleh komunitas IJABI di Kota Makassar seperti melaksanakan doa-doa dan melakukan berbagai kegiatan dakwah. Salah satu kegiatan dakwah yang dilaksanakan yaitu Haul Syahadah Imam Husain Cucunda Rasulullah (ASYURA) pada tahun 2017 silam. Kegiatan ini sudah berlangsung lama dikarenakan tidak adanya respon positif dari pihak pemerintah tentang kegiatan tersebut. Komunitas Syi'ah dengan mudahnya mempengaruhi mahasiswa-mahasiswa di kota Makassar melalui ajaran nikah mut'ah.

\section{DAFTAR PUSTAKA}

Abi, T.P. 2012. Mazhab Syiah. Jakarta: DPP ABI. Al-Quran Tafsir Jalalain \& Tafsir Ibnu Katsir Al-khotib, Sayyid Muhibudin.1984. Mengenal Pokok-pokok Ajaran Syi'ah Al-Imamiyah, Surabaya:PT.bina ilmu

As-Shallabi, Muhammad, Ali,Khawarij. 2011. Syi'ah dalam Timbangan Ahlussunnah wal Jamaah Pustaka Al-Kautsar.

As-Salus, Ali Ahmad. 2001. Ensiklopedi Sunnah-Syi'ah: Studi Perbandingan Hadits dan Fiqh. Vol. 2. Jakarta: Pustaka Al-Kautsar.

Atjeh, Aboebakar. 1980. Syi'ah: Rasionalisme dalam Islam. Kelantan: Pustaka Aman Press.

Budiman, Arief. 1997. Teori Negara: Negara, Kekuasaan, dan Ideologi, Jakarta, Gramedia.

Kahmad Dadang. 2000. Sosiologi Agama, Remaja Rosdakarya, Bandung.

Jafri, H. 1989. Awal dan sejarah perkembangan islam Syi'ah dari saqifah Imamah. Jakarta: Pustaka Hidayah.

Jurdi, Syarifuddin. 2014. Sosiologi Islam dan Masyarakat Modern: Teori, fakta, dan Aksi Sosial. Jakarta: Kencana.

Modarresee, R. 2005. Syi'ah dam sunnah mencari titik temu yang terabaikan. Penerbit Citra

Nashir, Haedar. 2006. Gerakan Islam Syariah: Reproduksi Salafiyah Ideologis di Indonesia Yogyakarta, Review Disertasi Doktor Sosiologi UGM. 
Putra, Fadillah. 2006. Gerakan Sosial. Malang. Averroes Press.

Putra, Rendra Graha Utomo. 2013.Gerakan Sosial Politik (Studi Kasus Gerakan Indonesia Tanpa Jaringan Islam Liberal). Jurusan IImu Politik. FISIP UNAIR.

[15]Tim Ahlul Bait Indonesia, 2012. Buka Putih Madzhab Syi'ah. September. 